\title{
PENGARUH MODEL GUIDED DISCOVERY LEARNING TERHADAP HIGH ORDER THINKING SKILLS SISWA KELAS XI
}

\author{
Mufida Nofiana ${ }^{1}$, Agus Prayitno ${ }^{2}$ \\ ${ }^{1}$ Universitas Muhammadiyah Purwokerto, ${ }^{2}$ Biologi SMA Negeri 1 Baturraden \\ email: mufidanofiana@ump.ac.id
}

\begin{abstract}
ABSTRAK
High Order Thingking Skills (HOTS) merupakan bagian dari tuntutan kurikulum 2013. Model Guided Discovery Learning (GDL) merupakan salah satu model yang sesuai untuk penerapan kurikulum 2013. Penelitian ini bertujuan untuk mengetahui pengaruh model GDL terhadap HOTS siswa pada materi jaringan hewan di kelas XI SMA Negeri 1 Baturraden. Subyek penelitian adalah siswa kelas XI MIPA 1 sebagai kelas control dan kelas XI MIPA 2 sebagai kelas eksperimen. Pengambilan sampel dilakukan dengan teknik cluster random sampling. Desain penelitian menggunakan post-test only control grup desain. Waktu penelitian dilaksanakan pada bulan Agustus-September 2019. Tahapan penelitian meliputi: tahap persiapan, tahap pelaksanaan, dan tahap evaluasi. Teknik analisis data menggunakan uji T, uji F, dan uji Eta. Hasil penelitian mendapatkan hasil bahwa: terdapat perbedaan nilai rata-rata HOTS siswa antara kelas eksperimen dan kelas control (nilai $\mathrm{sig}=0,01$ ) dengan nilai rata-rata HOTS siswa di kelas eksperimen lebih tinggi dibandingkan dengan nilai di kelas control. Penerapan model Guided Discovery Learning berpengaruh terhadap HOTS siswa (nilai sig = 0,01) dengan kekuatan pengaruh rendah (koefisien korelasi=0.392). Meskipun kekuatan pengaruh model GDL terhadap HOTS rendah, namun ada kepastian bahwa perbedaan nilai rata-rata HOTS siswa antara kelas eksperimen dan kelas kontrol disebabkan karena perbedaan model pembelajaran yang digunakan.
\end{abstract}

Kata kunci: Guided Discovery Learning, High Order Thinking Skills

\begin{abstract}
High Order Thinking Skills (HOTS) are part of the 2013 curriculum provisions in Indonesian. The Guided Discovery Learning (GDL) is one of the learning models that suits in the 2013 curriculum. This research aims to determine the effect of the GDL model on students' HOTS on animal tissue material in class XI MIPA of SMA Negeri 1 Baturraden. The research subjects were students of class XI MIPA 1 as a control class and class XI MIPA 2 as an experimental class. Sampling was done by cluster random sampling technique. The research design uses a post-test only control group design. The time of the research was conducted in August-September 2019. Stages of the research includes: preparation, implementation and evaluation. Data analysis techniques using the T test, F test, and Eta test. The Result of this research are: there are find difference in average value of HOTS students between the experimental class and the control class (sig = 0.01). The application of the Guided Discovery Learning
\end{abstract}


model affects HOTS students $($ sig $=0.01)$ with low strength (interaction coefficient $=$ 0.392). Although this power is low, there is certainty about the difference in the average value of HOTS students between the experimental class and the control class caused by differences in the learning model used.

Keywords: Guided Discovery Learning, High Order Thinking Skills

\section{PENDAHULUAN}

Kurikulum 2013 yang saat ini diterapkan di Indonesia menuntut siswa untuk mampu mengembangkan keterampilan berpikir kritis dengan penguatan pada pola belajar aktif mencari (Kemendikbud 2018). Keterampilan untuk dapat berpikir kritis yang dibebankan pada kurikulum 2013 merupakan bagian dari keterampilan berpikir tingkat tinggi (King, et all, 2010). Keterampilan berpikir tingkat tinggi (High order thinking skills) adalah keterampilan berpikir yang tidak hanya membutuhkan kemampuan mengingat saja, namun sudah mencapai keterampilan untuk menganalisis, mengevaluasi, dan mencipta (Anderson dan Krathwohl, 2001). Tuntutan kurikulum yang demikian hendaknya ditanggapi oleh guru di sekolah melalui perubahan pada proses pembelajaran yang mengarah kepada High Order Thingking Skills (HOTS).

Resnick (1987) dalam Thomson (2008) menyatakan bahwa High order thingking skills (HOTS) dapat didefinisikan sebagai proses berpikir kompleks dalam menguraikan materi, membuat kesimpulan, membangun representasi, menganalisis, dan membangun hubungan dengan melibatkan aktivitas mental yang paling dasar. Krathwohl (2002) menyatakan bahwa HOTS berada pada level kognitif mulai dari C4-C6 yang meliputi kemampuan menganalisis (analyzing), mengevaluasi (evaluating), dan mencipta (creating). Dalam pembelajaran di sekolah, pengembangan HOTS tidak hanya tampak pada soal evaluasi guru tetapi juga pada proses pembelajaran yang berlangsung di kelas.

Implementasi kurikulum 2013 yang berorientasi pada HOTS diharapkan mampu mencapai berbagai kompetensi pada peserta didik. Kompetensi tersebut antara lain: kemampuan berpikir kritis (critical thinking), kreatif dan inovtif (creative and innovative), kemampuan berkomunikasi (communication skills), kemampuan bekerja sama (collaborative), dan kepercayaan diri (confidence) (Dirjen GTK, 2018). HOTS diperlukan dalam suatu proses pembelajaran yang berorientasi pada pemecahan masalah (problem solving). Hal ini disebabkan karena selama proses pemecahan masalah oleh siswa dibutuhkan keterampilan berikir kritis dan keratif dalam mengambil keputusan, menganalisis semua asumsi yang muncul, serta melakukan investigasi berdasarkan data atau informasi untuk mendapatkan kesimpulan yang diinginkan.

Proses pembelajaran yang mengarah pada pengembangan HOTS menekankan pada pembelajaran yang berpusat pada siswa (student center learning). Salah satu model pembelajaran yang direkomendasaikan dalam kurikulum 2013 adalah Discovery Learning. Discovery Learning disebut juga sebagai model pembelajaran penyikapan/ penemuan 
adalah model yang digunakan untuk memahami konsep, arti, dan hubungan melalui proses intuitif untuk akhirnya dibuat sebuah kesimpulan (Dirjen GTK, 2018). Discovery terjadi apabila siswa terlibat dalam penggunaan proses mental untuk menemukan konsep dan prinsip yang sebelumnya tidak diketahui. Pada pembelajaran di sekolah, model Discovery Learning dapat dimodifikasi menjadi Guided Discovery Learning (Discovery Learning terbimbing). Modifikasi ini dapat dilakukan sesuai dengan kondisi siswa dan kebutuhan guru terhadap proses pembelajaran.

Guided discovery learning (GDL) adalah model pembelajaran yang dilakukan oleh siswa untuk menemukan konsep, prinsip, maupun teori secara mandiri dengan bantuan guru sebagai fasilitator. GDL dapat juga diartikan bahwa dalam pelaksanaan penemuan oleh siswa, dilaksanakan atas petunjuk dari guru (Hanafiah dan Suhana, 2010). Pada prinsip GDL, siswa didorong untuk mengidentifikasi apa yang ingin diketahui dilanjutkan dengan mencari informasi sendiri kemudian mengorganisasi menjadi sebuah kesimpulan (Dirjen GTK, 2018). Pembelajaran ini dapat dilakukan dengan diawali pertanyaan/ stimulus guru yang mengarahkan siswa untuk mencapai tujuan pembelajaran melalui penarikan kesimpulan.

Langkah kegiatan model GDL yang dilakukan di kelas sama dengan pelaksanaan Discovery Learning murni. Syah (2010) mengungkapkan sintak model GDL meliputi: stimulation (pemberian rangsang), problem statement (pernyataan/ identifikasi masalah), data collection (pengumpulan data), data processing (pengolahan data), verification (pembuktian), dan generalization (menarik kesimpulan/generalisasi).

Belajar penemuan melalui model GDL mampu meningkatkan kemampuan berpikir tingkat tinggi siswa baik dalam hal berpikir kritis, berpikir kreatif, berpiki analitis, serta penguasaan konsep. Hal ini sejalan dengan penelitian dari Afian, dkk (2017) yang menyimpulkan bahwa perangkat pembelajaran yang didesain dengan model GDL berpengaruh secara positif terhadap keterampilan berpikir kreatif dan penguasaan konsep. Sartono, dkk, (2017) juga menyatakan bahwa pembelajaran yang berorientasi pada GDL memiliki pengaruh yang lebih baik terhadap kemampuan berpikir analisis siswa SMA.

Pembelajaran dengan GDL dapat dimodifikasi untuk meningkatkan kemampuan berpikir analisis yang merupakan bagian dari high order thinking skills. Wulandari, dkk, (2018) membuat konsep desain dari modifikasi GDL yang mengintegrasikan sintak guided discovery learning dengan domain kognitif taksonomi marzano. Keunggulan dari pembelajaran GDL dalam proses pembelajaran dikemukakan oleh beberapa ahli. Bruner dalam (Suparno, 2009) menyebutkan kelebihan model GDL antara lain: membantu mengembangkan penguasaan keterampilan dan proses kognitif siswa, mengarahkan siswa untuk belajar secara mandiri dan terlibat dalam penemuan konsep, mampu mengembangkan potensi intelektual siswa dalam memecahkan persoalan, membuat pembelajaran lebih bermakna yang ditandai dengan ingatan lebih lama. Pembelajaran di kelas yang diterapkan dengan model GDL mampu meningkatkan rasa ingin tahu siswa 
(Gusmalisa, 2015), kemampuan berpikir kritis (Agustina, dkk, 2015).

Hasil penelitian pendahuluan di SMA Negeri 1 Baturraden menunjukkan bahwa pembelajaran biologi yang berorientasi HOTS belum menunjukkan hasil yang maksimal. Hal ini disebabkan karena model pembelajaran yang digunakan guru di sekolah belum mengembangkan kemampuan siswa untuk menganalisis, mengevaluasi, maupun mencipta. Guru masih mendominasi pembelajaran dengan metode ceramah yang diselingi dengan tanya jawab. Meskipun guru memberi kesempatan siswa untuk berdiskusi, namun hampir sebagian besar informasi yang diperoleh siswa disampaikan langsung oleh guru dengan metode ceramah. Oleh karena itu, penelitian ini bertujuan untuk mengetahui pengaruh model Guided Discovery Learning terhadap HOTS siswa dan mengetahui adakah perbedaan HOTS siswa antara kelas eksperimen dan kelas control yang digunakan.

\section{METODE PENELITIAN}

Penelitian dilaksanakan di SMA Negeri 1 Baturraden dengan subyek penelitian adalah siswa kelas XI MIPA 1 sebagai kelas kontrol dan XI MIPA 2 sebagai kelas eksperimen. Pengambilan sampel dilakukan dengan teknik cluster random sampling. Desain penelitian menggunakan post-test only control group desain. Waktu penelitian dilaksanakan pada bulan Agustus-September 2019.

Penelitian yang dilakukan merupakan jenis penelitian eksperimen semu (quasi experiment), hal ini disebabkan karena peneliti tidak dapat mengontrol keseluruhan variabel yang dimungkinkan ikut berpengaruh terhadap hasil penelitian. Tahapan penelitian meliputi:

1. Tahap persiapan

Tahap persiapan dilakukan dengan mengambil sampel penelitian dari populasi. Populasi yang digunakan adalah pada seluruh siswa kelas XI MIPA yang akan menempuh materi biologi pada KD 3.4 dengan topik jaringan hewan. Kelas yang terpilih adalah XI MIPA 1 dan XI MIPA 2. Kedua kelas selanjutnya diuji kemampuan awal berpikirnya untuk memastikan tidak ada perbedaan kemampuan berpikir siswa sebelum penerapan model GDL. Selanjutnya menyiapkan perangkat pembelajaran dan instrument evaluasi HOTS

2. Tahap pelaksanaan

Pelaksanaan penelitian dilakukan dengan menerapkan desain pembelajaran di kelas eksperimen dengan model GDL dan di kelas kontrol dengan model kontekstual. Selama proses pelaksanaan penelitian dipastikan seluruh sintak model pembelajaran yang direncanakan dilakukan oleh guru, kontrol tersebut dilakukan melalui lembar observasi keterlaksanaan sintak.

3. Tahap evaluasi

Evaluasi dilakukan untuk mengetahui keterampilan berpikir tingkat tinggi siswa (HOTS) setelah penerapan model pembelajaran GDL di kelas eksperimen dan model kontekstual di kelas kontrol. Intrumen evaluasi yang digunakan adalah instrument yang dirancang untuk mengukur HOTS. Bentuk instrumen evaluasi menggunakan two-tier multiple choice question (pilihan 
ganda bertingkat). Two-tier multiple choice question adalah modifikasi dari bentuk soal pilihan ganda yang terdiri dari dua tingkatan soal. Soal bentuk ini dapat digunakan untuk mengukur keterampilan berpikir tingkat tinggi (Nofiana, dkk, 2014). Indikator yang digunakan dalam pengembangan instrument evaluasi mengacu pada taksonomi bloom revisi dari Anderson dan Krathwohl (2001) pada level C4-C6 (menganalisis, mengevaluasi, dan mencipta).
Teknik analisis data dalam penelitian menggunakan uji T, uji F, dan uji Eta. Uji T digunakan untuk mengetahui perbedaan HOTS siswa pada kelas eksperimen dan kelas kontrol. Uji $\mathrm{F}$ digunakan untuk mengetahui adakah pengaruh model GDL terhadap HOTS siswa di kelas eksperimen. Uji eta digunakan untuk mengetahui tingkat pengaruh model GDL terhadap HOTS siswa. Keeratan hubungan atau korelasi antar variabel dapat diketahui dari kategori koefisien korelasi (KK) seperti pada Tabel 1 berikut ini.

Tabel 1. Kategori Koefisien Korelasi

\begin{tabular}{cc}
\hline Interval nilai & Kekuatan hubungan \\
\hline $\mathrm{KK}=0$ & Tidak ada \\
\hline $0,00<\mathrm{KK} \leq 0,20$ & $\begin{array}{c}\text { Sangat rendah atau lemah } \\
\text { sekali }\end{array}$ \\
\hline $0,20<\mathrm{KK} \leq 0,40$ & Rendah atau lemah tapi pasti \\
\hline $0,40<\mathrm{KK} \leq 0,70$ & Cukup berarti atau sedang \\
\hline $0,70<\mathrm{KK} \leq 0,90$ & Tinggi atau kuat \\
\hline $0,90<\mathrm{KK} \leq 1,00$ & Sangat tinggi atau kuat sekali, \\
& dapat diandalkan \\
\hline $\mathrm{KK}=1$ & Sempurna \\
\hline Sumber: (Misbahudin \& Hasan, 2014)
\end{tabular}

\section{HASIL DAN PEMBAHASAN}

Pengaruh model pembelajaran GDL terhadap HOTS siswa ditunjukkan melalui perhitungan uji beda dan uji korelasi. Sebelum melakukan pengujian, perlu dilakukan uji prasyarat untuk menentukan uji statistic yang akan digunakan (statistic parametric atau non parametric). Hasil pengujian prasyarat ditunjukkan pada Tabel 2 dan Tabel 3.

Tabel 2. Uji Normalitas Nilai HOTS Pada Kelas XI MIPA 1 dan XI MIPA 2

\begin{tabular}{lll}
\hline & $\begin{array}{l}\text { Nilai } \\
\text { Sig Kolmogorov-smirnov }\end{array}$ & Keputusan* \\
\hline XI MIPA 1 & 0.200 & Normal \\
\hline XI MIPA 2 & 0.79 & Normal \\
\hline *jika nilai sig $>0.05$ data terdistribusi normal &
\end{tabular}


Tabel 3. Uji Homgenitas Nilai HOTS Pada Kelas XI MIPA 1 dan XI MIPA 2

\begin{tabular}{ccc}
\hline & Nilai & Keputusan* \\
\hline Nilai HOTS & 0.242 & Homogen \\
\hline *jika nilai sig >0.05 data homogen & dilanjutkan dengan uji & statistic parametric \\
Hasil uji prasyarat menunjukkan data & yakni menggunakan uji independent sample \\
istribusi normal dan homogen. Pengujian & T-test, uji F, dan uji eta.
\end{tabular}

Tabel 4. Nilai Rata-rata HOTS Siswa

\begin{tabular}{ccc}
\hline Kelas & Jumlah siswa & Nilai rata-rata HOTS siswa \\
\hline XI MIPA 1 & 30 & 51.73 \\
\hline XI MIPA 2 & 33 & 60.67 \\
\hline
\end{tabular}

Tabel 5. Uji Independent Sample T-test nilai HOTS siswa

\begin{tabular}{cccc}
\hline & Nilai $\mathrm{t}$ & Nilai sig & Keputusan* \\
\hline Nilai HOTS & 3.332 & 0.01 & Ada beda rata-rata \\
\hline *jika nilai
\end{tabular}

*jika nilai sig $<0.05$ menunjukkan ada perbedaan nilai rata-rata dari sampel pengujian

Tabel 6. Uji F antara Model GDL dengan Nilai HOTS Siswa

\begin{tabular}{ccccc}
\hline & Nilai F hitung & F Tabel & Nilai sig & Keputusan* \\
\hline $\begin{array}{c}\text { Regresi } \\
\text { linear }\end{array}$ & 11.104 & 4.00 & 0.01 & Ada pengaruh \\
\hline
\end{tabular}

*jika nilai $\mathrm{F}$ hitung $>\mathrm{F}$ tabel dan nilai sig $<0.05$ menunjukkan ada pengaruh variable bebas terhadap variable terikat.

Tabel 5. Uji Eta Pengaruh Model GDL terhadap HOTS

\begin{tabular}{ccc}
\hline & Nilai Eta* & Keputusan* \\
\hline Model GDL dan HOTS & 0.392 & Berpengaruh rendah \\
\hline
\end{tabular}

*Nilai korelasi Eta antara $0,20<\mathrm{KK} \leq 0,40$.menunjukkan pengaruh yang rendah tapi memiliki kepastian pengaaruh (Misbahudin \& Hasan, 2014)

Analisis data yang dilakukan untuk mengetahui adakah pengaruh model GDL terhadap HOTS siswa ditunjukkan pada Tabel 5 dan Tabel 6. Tabel 5 menunjukkan terdapat perbedaan HOTS siswa antara kelas yang diajar dengan Model GDL dan yang tidak diajar dengan model GDL. Model pembelajaran GDL memiliki sintak yang terdiri dari: stimulation (pemberian rangsang), problem statement (pernyataan/ identifikasi masalah), data collection (pengumpulan data), data processing (pengolahan data), verification (pembuktian), dan generalization (menarik kesimpulan/ generalisasi). Perbedaan HOTS pada kelas eksperimen dan kelas kontrol disebabkan karena sintak pembelajaran pada model GDL di kelas eksperimen dapat mengakomodasi siswa untuk mampu menganalisis, mengevaluasi, dan mencipta.

Tahap stimulation atau pemberian rangsang yang dilakukan pada kegiatan 
pembelajaran, diawali dengan guru memberikan suatu gambaran yang dapat memotivasi siswa untuk mengikuti materi yang akan dipelajari. Sesuatu tersebut dapat berupa permasalahan yang harus dipecahkan, kejadian yang bersifat kontekstual, maupun media pembelajaran yang memfasilitasi siswa untuk melakukan kegiatan orientasi masalah. Kegiatan stimulasi dalam penelitian dilakukan dengan menayangkan video organ manusia serta jaringan-jaringan penyusunnya serta mengamati torso jaringan penyusun organ manusia. Pada kegiatan ini, guru memotivasi siswa melalui kegiatan pengamatan untuk menarik minat siswa mempelajari materi tersebut secara lebih mendalam.

Kegiatan pengamatan dalam tahap stimulasi bertujuan untuk membangun rasa ingin tahu siswa. Melalui kegiatan pengamatan, siswa akan menemukan hal-hal menarik untuk dapat dipelajari lebih lanjut. Kegiatan pengamatan dapat dilanjutkan dengan problem statement atau identifikasi masalah. Tahap identifikasi masalah mampu meningkatkan kemampuan menganalisis (C4) melalui penyajian fenomena yang dihadirkan dan merumuskan pernyataan.

Tahap pengumpulan data atau data collection merupakan kegiatan yang bertujuan untuk mencari jawaban atas permasalahan yang ditemukan dalam kegiatan sebelumnya. Data collection dalam penelitian dilakukan melalui berbagai kegiatan seperti praktikum, diskusi kelompok, dan literature review. Kegiatankegiatan tersebut difasilitasi melalui lembar kerja peserta didik yang didisain untuk meningkatkan kemampuan menganalisis, mengevaluasi, dan mencipta. Kegiatan ini dapat membantu siswa mengumpulkan infromasi dari berbagai sumber, menyeleksi informasi yang dibutuhkan sampai menemukan solusi yang dapat dipertahankan (Arends, 2008).

Tahap pengumpulan data dilanjutkan dengan data processing atau pengolahan data. Pada kegiatan penelitian data processing dilakukan melalui penyajian data dalam bentuk tabel maupun gambar. Penyajian data dapat membantu siswa untuk mengevaluasi pertanyaan dan membangun kreativitas. Arends, (2008) mengemukakan bahwa penyajian data disebut juga solution presentation and reflection sehingga dapat digunakan untuk meningkatkan kemampuan mengevaluasi siswa terhadap permasalahan yang sedang dipecahkan. Kemampuan ini dibuktikan melalui kegiatan verification atau pembuktian.

Tahap verification atau pembuktian merupakan kegiatan untuk menngklarifkasi hasil penemuan atau penyelidikan siswa terhadap solusi permasalahan yang ditemukan. Dalam penelitian, tahap verifikasi dilakukan melalui kegiatan presentasi dan diskusi kelas. Salah satu kelompok siswa maju untuk mempresentasikan hasil pengumpulan data, kelompok lain mengkritisi dengan membandingkan hasilnya dengan hasil pekerjaan kelompok sendiri. Jika hasilnya berbeda, guru akan memfasilitasi siswa untuk menemukan pembenaran atau melakukan klarfikasi. Kegiatan verifikasi dapat meningkatkan kemampuan menganalisis dan mengevaluasi siswa.

Hasil dari kegiatan verifikasi adalah penarikan kesimpulan atau generalization atas hasil pengumpulan data. Kesimpulan ini 
berupa konsep materi yang telah terverifikasi kebenarannya. Arends (2008) menyatakan bahwa kegiatan penarikan kesimpulan dapat digunakan untuk menganalisis dan mengevaluasi proses berpikir, serta keterampilan intelektual siswa dalam mencari solusi atas permasalahan yang dikemukakan.

Model pembelajaran GDL terbukti berpengaruh terhadap HOTS siswa pada materi jaringan hewan (Tabel 6). Meskipun kekuatan pengaruh model tersebut rendah (Tabel 7) namun ada kepastian bahwa perbedaan nilai rata-rata HOTS siswa di kelas eksperimen dan kelas control disebabkan karena perbedaan model pembelajaran yang digunakan (Tabel 4). Ada banyak factor yang menyebabkan HOTS siswa rendah. Faktor internal seperti kondisi fisiologis dan psikologis siswa serta factor eksternal seperti lingkungan belajar dan keluarga akan mempengaruhi hasil belajar siswa termasuk HOTS siswa (Nofiana, 2014). Sikap ataupun motivasi siswa yang ingin selalu berpikir mudah dengan menjawab pertanyaan secara langsung tanpa melalui proses berpikir lebih, kompetensi guru yang kurang dalam mengajarkan siswa untuk memiliki HOTS, persepsi guru terhadap siswa dalam mengajar HOTS, penilaian HOTS yang menggunakan instrument HOTS terstandar ataupun menggunakan instrument alternative dikembangkan untuk mengukur keberhasilan pembelajaran HOTS (Yen \& Halili, 2015).

Model pembelajaran GDL memiliki sintak pembelajaran yang mampu memfasilitasi siswa untuk berpikir kritis dan kreatif yang merupakan bagian dari kemampuan berpikir tingkat tinggi atau HOTS. Perangkat pembelajaran yang dikembangkan dengan model GDL mampu meningkatkan kemampuan berpikir kreatif dan penguasaan konsep siswa (Afian, dkk, 2017), kemampuan berpikir kritis (Agustina, dkk, 2015), serta kemampuan analisis ( Sartono, dkk, 2017). Pada penelitian yang dilakukan, kegiatan siswa untuk mengidentifikasi masalah baik secara mandiri maupun berkelompok mampu meningkatkan kemampuan berpikir kritis siswa. Kegiatan pengumpulan data, pengolahan data, serta pembuktian mampu meningkatkan kemampuan berpikir kritis, kreatif, dan analisis siswa. Kegiatan menyimpulkan juga mampu meningkatkan kemampuan berpkir kritis dan analisis siswa.

Pembelajaran dengan model GDL dapat dikatakan sebagai model pembelajaran yang berorientasi pada kegiatan penemuan atau penyelidikan melalui kegiatan pengumpulan data. Model pembelajaran tersebut dapat digunakan untuk meningkatkan rasa ingin tahu siswa terhadap materi. Model discovery mampu meningkatkan aktivitas siswa selama proses pembelajaran di kelas (Bahri, 2015). Kegiatan pengumpulan data tersebut akan memfasilitasi siswa untuk menemukan konsep materi selama proses pembelajaran.

\section{KESIMPULAN}

Model Guided Discovery Learning bepengaruh terhadap High Order Thinking Skills (HOTS) siswa pada materi jaringan hewan $($ sig=0,01) dengan pengaruh yang rendah (koefisien korelasi $=0,392$ ). Meskipun kekuatan pengaruhnya rendah, namun ada kepastian bahwa perbedaan nilai rata-rata HOTS siswa antara kelas eksperimen dan kelas kontrol disebabkan karena perbedaan model pembelajaran yang 
digunakan $(\operatorname{sig}=0,01)$. Hal ini juga dikuatkan dengan nilai rata-rata HOTS siswa di kelas eksperimen lebih tinggi dibandingkan dengan nilai di kelas control.

\section{UCAPAN TERIMAKASIH}

Terimakasih kepada Direktorat Pembelajaran; Direktorat Jenderal Pembelajaran dan Kemahasiswaan; Kementerian Riset, Teknologi, dan Pendidikan Tinggi atas terpilihnya Universitas Muhammadiyah Purwokerto sebagai salah satu penerima Hibah Penugasan Dosen di sekolah (PDS) sehingga artikel ini dapat disusun dengan baik.

\section{DAFTAR PUSTAKA}

Afian, T., Ibrahim, M., \& Agustini, R. (2017). Pengembangan Perangkat Pembelajaran Sains Berorientasi Guided Discovery Learning untuk Mengajar Kemampuan Berpikir Kreatif dan Penguasaan Konsep. JPPS (Jurnal Penelitian Pendidikan Sains), 4(1), 488494.

Agustina, M., Achmad, A., \& Yolida, B. (2015). Pengaruh Model Discovery Learning terhadap Kemampuan Berpikir Kritis dan Hasil Belajar Siswa. Jurnal Bioterdidik: Wahana Ekspresi Ilmiah, Vol 3 No 6, 7-17.

Anderson, L.W dan D.R Krathwohl. 2001. A Taxonomy for Learning, Teaching, and Assesing. New York: Longman

Arends, R. (2008). Learning to Teach (9th ed). Yogyakarta: Pustaka Pelajar.

Bahri, A. S. (2015). The Influence of learning model guided findings of student learning outcomes. International journal of scientific and technology research, Vol 4, Issue 3, 77-79.

Direktorat Jenderal Guru dan Tenaga Kependidikan, Kementerian Pendidikan dan Kebudayaan. 2018. Buku Pegangan Pembelajaran Berorientasi Pada Keterampilan Berpikir Tingkat Tinggi. Jakarta: Direktorat Jenderal Guru dan Tenaga Kependidikan, Kementerian Pendidikan dan Kebudayaan.

Gusmalisa, D. (2015). Penerapan Model Discovery Learning Terhadap Hasil Belajar Siswa Pada Mata Pelajaran Geografi. JPG: Jurnal Penelitian Geografi, 1-11.

Hanafiah, Nanang dan Cucu Suhana. 2010. Konsep Strategi Pembelajaran. Bandung: PT Refika Aditama

King, JF; Goodson, Ludwika, dan Rohani, Faranak. 2010. Higher Order Thinking Skills, Definition, Teaching Strategis, Assesment. A Publication of The Educational Services Program. $\underline{\text { www.Cala.fsu.edu }}$

Krathwohl, D.R. 2002. A revision of Bloom's Taxonomy : An Overview- Theory Into Practice, Volume 41, Number 4, Autumn 2002. College of Education, The Ohio State University.

Misbahudin \& Hasan, I. (2014). Analisa Data Penelitian dengan Statistik. Jakarta: Bumi Aksara.

Nofiana, M; Sajidan; Puguh Karyanto (2014). Pengembangan Two-Tier Multiple Choice 
Question untuk Mengukur Keterampilan Berpikir Tingkat Tinggi Siswa pada Materi Kingdom Plantae. Jurnal Inkuiri, Vol 3, No II, 60-74

Peraturan Menteri Pendidikan dan Kebudayaan No 36 Tahun 2018 Tentang Perubahan atas Peraturan Menteri Pendidikan Dan Kebudayaan No 59 Tahun 2014 Tentang Kurikulum 2013.

Sartono, N., Rusdi, \& Handayani, R. (2017). Pengaruh Pembelajaran Process Oriented Guided Inquiry Learning (POGIL) dan Discovery Learning Terhadap Kemampuan Berpikir Analisis Siswa SMA N 27 Jakarta Pada Materi Sistem Imun. Biosfer: Jurnal Pendidikan Biologi (BiosferJPB), Vol 10 No 1, 58-64.

Suparno, P. (2009). Metodologi Pembelajaran Fisika Konstruktivistik dan Menyenangkan. Yogyakarya: Universitas Sanata Drama.

Syah, muhibbin. 2010. Psikologi pendidikan dengan pendekatan baru. Bandung: PT. Remaja Rosdakarya

Thomson, Tony. 2008. Mathematics Teachers' Interpretation of Higher Order Thinking In Bloom's Taxonomy. International Electronic Journal of Mathematics Education Volume 3, Number 2, July 2008.

Wulandari, A., Sa'dija, C., As'ari, A., \& Raharjo, S. (2018). Modifified Guided Discovery Learning: A conceptual Framework for Designing Learning Model Using Guided Discovery to
Promote Student's Analytical Thinking Skills. Journal of Physics: Conference Series 1028, 1-10.

Yen, T. S., \& Halili, S. H. (2015, Vol 3 Issue 2). Effective Teaching of Higher-Order Thinking (HOT) in Education. The Online Journal of Distance Education and e-learning, 41-47. 